ACTA UNIVERSITATIS WRATISLAVIENSIS

No 4078

Studia nad Autorytaryzmem i Totalitaryzmem 43, nr 4 Wrocław 2021

https://doi.org/10.19195/2300-7249.43.4.1

\author{
MACIEJ BŁAŻEWSKI \\ ORCID: 0000-0003-2812-8199 \\ Uniwersytet Wrocławski \\ maciej.blazewski@uwr.edu.pl
}

\title{
Założenie nadrzędności interesu społecznego nad interesem jednostkowym w planowaniu przestrzennym jako przejaw autorytarnych tendencji prawodawcy w ustawie z dnia 12 lipca 1984 roku o planowaniu przestrzennym
}

Słowa kluczowe: planowanie przestrzenne, interes społeczny, plany gospodarcze, autorytaryzm.

\author{
ASSUMPTION OF THE SUPERIORITY OF SOCIAL INTEREST \\ OVER INDIVIDUAL INTEREST IN SPATIAL PLANNING \\ AS A MANIFESTATION OF AUTHORITARIAN TENDENCIES
}

OF THE LEGISLATOR IN THE ACT OF 12 JULY 1984 ON SPATIAL PLANNING

\section{Abstract}

The Act of 12 July 1984 on Spatial Planning ensured the primacy of social interest over individual interest. This superiority was a manifestation of the authoritarian tendencies of the legislator. The normative measures ensuring this supremacy were the principle of planned development and the linking of spatial development plans with social and economic plans.

Keywords: urban planning, social interest, economic plans, authoritarianism.

\section{Wstęp}

W polskim porządku prawnym w okresie Polskiej Rzeczypospolitej Ludowej przyjęto socjalistyczny postulat nadrzędności dobra społecznego względem dobra jednostki. Postulat ten przekładał się na zapewnienie nadrzędności interesu 
społecznego właściwego dobru społecznemu względem interesu jednostkowego. Nadrzędność ta miała autorytarne inklinacje ze względu na jej związek z ustanowieniem przez prawodawcę podporządkowania jednostki dobru społecznemu, rozumianemu z perspektywy ideologii socjalizmu. Środkami normatywnymi zapewniającymi nadrzędność interesu społecznego nad interesem jednostkowym były zasada zabudowy planowej oraz powiązanie planów zagospodarowania przestrzennego z planami społeczno-gospodarczymi. Środki te zostały ustanowione między innymi w ustawie $\mathrm{z}$ dnia 12 lipca 1984 roku o planowaniu przestrzennym $^{1}$. Prawodawca $\mathrm{w}$ tej ustawie podtrzymywał założenia inkorporowane do poprzednich regulacji, w tym dekretu $\mathrm{z}$ dnia 2 kwietnia 1946 roku o planowym zagospodarowaniu przestrzennym kraju ${ }^{2}$ oraz ustawy z dnia 31 stycznia 1961 roku o planowaniu przestrzennym ${ }^{3}$.

\section{Autorytarny charakter nadrzędności interesu społeczności nad interesem jednostkowym}

Jednym z założeń ideologii socjalizmu, która dominowała w okresie Polskiej Rzeczypospolitej Ludowej, było uznanie nadrzędności interesu społecznego nad interesem jednostkowym. Zapewnienie tej nadrzędności miało w okresie funkcjonowania PRL autorytarny charakter. W literaturze podkreśla się, że autorytaryzm jest związany z ograniczeniami praw i wolności obywateli ${ }^{4}$. Prawodawca autorytarny ingeruje $\mathrm{w}$ te prawa i wolności, szczególnie gdy jest to związane $\mathrm{z}$ realizacją celów ideologicznych ${ }^{5}$. W związku z tym sytuacja jednostki powinna była być podporządkowana dobru społecznemu ze względu na dominujące założenie dążenia do modelu kolektywistycznej organizacji społeczeństwa 6 . Założenie to

${ }^{1}$ Ustawa z dnia 12 lipca 1984 roku o planowaniu przestrzennym (Dz.U. z 1984 r. Nr 35, poz. 185).

2 Dekret $\mathrm{z}$ dnia 2 kwietnia 1946 roku o planowym zagospodarowaniu przestrzennym kraju (Dz.U. z 1946 r. Nr 16, poz. 109).

${ }^{3}$ Ustawa z dnia 31 stycznia 1961 roku o planowaniu przestrzennym (Dz.U. z 1961 r. Nr. 7, poz. 47).

4 R. Tokarczyk podkreśla stopniowalny charakter autorytaryzmu, zależny od zakresu przymusu wobec obywateli i ograniczeń ich wolności; idem, Autorytaryzm - dociekanie istoty pojęcia, „Historia i Polityka” 2009-2010, nr 2-3, s. 40.

5 Jak zauważa W. Paruch, rządy autorytarne ingerują w sferę gospodarczą. Ingerencja ta ma charakter pośredni poprzez wzmożoną działalność regulacyjną, a także bezpośredni — poprzez rozbudowę sektora państwowego w gospodarce; idem, Autorytaryzm w Europie XX wieku. Zarys analizy politologicznej cech systemu politycznego, „Annales Universitatis Mariae Curie-Skłodowska. Sectio K. Politologia” 16, 2009, nr 1, s. 142.

6 Jak podkreśla R. Kania, teoretycy organizacji socjalistycznej wskazywali, że model kolektywistycznej organizacji społeczeństwa bazował na dwóch uzasadnieniach: ideologicznym, ze względu na dogmaty marksistowskie, oraz prakseologicznym, ze względu na domniemanie więk- 
odnosiło się między innymi do prawa własności, w którym wyróżniono własność społeczną oraz własność prywatną. Własność społeczna obejmowała głównie socjalistyczną własność państwową, która zgodnie z założeniami ideologii socjalistycznej miała stanowić gwarancję dobrobytu zarówno całego narodu, jak i każdego obywatela ${ }^{7}$.

\section{Zasada zabudowy planowej}

Zasada zabudowy planowej była środkiem normatywnym zapewniającym nadrzędność interesu społecznego. Została wprowadzona do polskiego porządku prawnego dekretem z dnia 2 kwietnia 1946 roku o planowym zagospodarowaniu przestrzennym $\mathrm{kraju}^{8}$, a następnie potwierdzona w przepisach ustawy z dnia 31 stycznia 1961 roku o planowaniu przestrzennym ${ }^{9}$. Prawodawca, uchwalając ustawę z dnia 12 lipca 1984 roku o planowaniu przestrzennym, ponownie ustanowił tę zasadę. W świetle art. 6 tej ustawy „działalność wpływająca na sposób zagospodarowania oraz wykorzystania gruntów może być podjęta tylko wówczas, gdy jest zgodna z ustaleniami planów zagospodarowania przestrzennego". Jak słusznie podkreśla M. Szewczyk, zasada zabudowy planowej znacząco ograniczała prawo własności, którego przedmiotem jest nieruchomość. Wyznacznikiem uprawnień właścicielskich względem tej nieruchomości była treść planów zagospodarowania przestrzennego. Źródłem prawa zabudowy nieruchomości była zgoda organu administracji państwowej wyrażona poprzez objęcie tej nieruchomości planem miejscowym określającym uprawnienie do korzystania z niej na konkretne cele ${ }^{10}$. Zasada zabudowy planowej stanowiła tym samym przeciwieństwo zasady

szej sprawności działania organizacji społecznych; idem, Między ideologia i praxis. Organizacja socjalistyczna w PRL w latach 1956-1981, „Studia nad Autorytaryzmem i Totalitaryzmem” 41, 2019, nr 4, s. 218-219.

7 J. Górski, Kilka uwag w sprawie własności, „Nowe drogi” 1951, nr 6, s. 86-87, cyt. za: M. Bużowicz, Ewolucja prawa własności w Polsce Ludowej w latach 1944-1956, „Wrocławskie Studia Erazmiańskie. Studia Erasmiana Wratislaviensia” 2016, nr 10, s. 496.

${ }^{8} \mathrm{~W}$ świetle art. 1 dekretu z dnia 2 kwietnia 1946 roku o planowym zagospodarowaniu przestrzennym kraju wszystkie poczynania publiczne i prywatne w zakresie użycia terenu i rozmieszczenia ludności powinny być dostosowane do postanowień planów zagospodarowania przestrzennego. Problematykę zasady planowej zabudowy w tym dekrecie przedstawia szerzej M. Szewczyk, Wolność budowlana i zasada zabudowy planowej, ,Przegląd Budowlany” 2013, nr 6, s. 24.

9 Zasada zabudowy planowej nie była zasadą dyrektywalną wyrażoną wprost w ustawie z dnia 31 stycznia 1961 roku o planowaniu przestrzennym, lecz była zasadą opisową, możliwą do odczytania na podstawie interpretacji przepisów tej ustawy. Problematykę ograniczeń prawa własności przez przepisy tej ustawy przedstawia szerzej M. Szewczyk, Rozwój regulacji prawnych w Polsce, [w:] Prawo zagospodarowania przestrzennego, red. Z. Leoński, M. Szewczyk, M. Kruś, Warszawa 2019, s. 50-51.

10 M. Szewczyk, Wolność budowlana..., s. 24. 
wolności zabudowy, będącej podstawą przepisów prawa o planowaniu i zagospodarowaniu przestrzennym w państwach o ustroju liberalno-demokratycznym ${ }^{11}$.

Zasada zabudowy planowej wpływała na zachowanie znaczącej nierównowagi pomiędzy interesem jednostkowym a interesem społecznym. $Z$ jednej strony, wpływała na sposób realizacji interesu jednostkowego: jeżeli nieruchomość nie była objęta planem miejscowym, to jej właściciel nie mógł realizować interesu jednostkowego w postaci zabudowy tej nieruchomości w sposób zgodny ze swoją wolą. Gdy nieruchomość była objęta planem miejscowym, to realizacja interesu jednostkowego obejmująca jej zabudowę była możliwa jedynie w sposób zgodny $\mathrm{z}$ ustaleniami tego planu ${ }^{12}$. $\mathrm{Z}$ drugiej strony, zasada zabudowy planowej ugruntowała ochronę interesu społecznego. Przestrzeń mogła być zabudowana jedynie w sposób określony w planie miejscowym, którego treść powinna odpowiadać interesowi społecznemu. Założenie realizacji tego interesu determinowało treść tego planu, na co wskazuje katalog wartości, których ochrona stanowiła cel planowania przestrzennego. W świetle art. 1 ustawy z dnia 12 lipca 1984 roku o planowaniu przestrzennym katalog chronionych wartości obejmował poprawę jakości życia społeczeństwa, zachowanie równowagi przyrodniczej, ochronę dóbr kultury, zwiększenie efektywności procesów gospodarczych i podnoszenie zdolności obronnej państwa. Wartości te były związane bezpośrednio z interesem społecznym. Należy podkreślić, że prawodawca pominął potrzebę ochrony interesu jednostkowego jako celu planowania przestrzennego.

Przepisy prawa ustanawiające zasadę zabudowy planowej obowiązywały do dnia 1 stycznia 1995 roku, kiedy weszła w życie ustawa z dnia 7 lipca 1994 roku o zagospodarowaniu przestrzennym ${ }^{13}$. Ustawa ta znosiła tę zasadę i przywracała zasadę wolności zabudowy odnoszącą się do prywatnych zamierzeń inwestycyjnych $^{14}$.

11 Podkreślenia wymaga, że przepisy prawa ustanawiające zasadę zabudowy planowej uchylały jednocześnie zasadę wolności zabudowy, a nie zasadę wolności budowlanej. Zasada wolności budowlanej jest właściwa regulacjom procesu budowlanego, którego przedmiotem jest realizacja zamierzenia budowlanego, a nie — zabudowy nieruchomości gruntowej. Szerzej problematykę zasady wolności budowlanej przedstawia M. Błażewski, Zasada wolności budowlanej. Studium administracyjnoprawne, Wrocław 2016, s. 33.

${ }^{12}$ W świetle wyroku NSA z dnia 7 sierpnia 2013 roku zasada zabudowy planowej oznaczała, że terenem, który zgodnie z przepisami o planowaniu przestrzennym nie był przeznaczony pod zabudowę, był nie tylko teren przeznaczony w istniejącym planie ogólnym lub szczegółowym na inne cele lub pod innego rodzaju zabudowę, lecz także teren nieprzeznaczony pod zabudowę ze względu na brak takich planów. Wyrok NSA z dnia 7 sierpnia 2013 roku, II OSK 165/12, CBOSA.

13 Ustawa z dnia 7 lipca 1994 roku o zagospodarowaniu przestrzennym (Dz.U. z 1994 r. Nr 89, poz. 415).

14 W świetle art. 2 ust. 2 ustawy z dnia 7 lipca 1994 roku o zagospodarowaniu przestrzennym w przypadku braku miejscowego planu zagospodarowania przestrzennego określenie przeznaczenia i ustalenie warunków zagospodarowania terenu następuje w decyzji o warunkach zabudowy i zagospodarowaniu terenu, wydanej na podstawie obowiązujących ustaw. Jak słusznie podkreśla M. Szewczyk, zasada zabudowy planowej przestała obowiązywać dla zamierzeń prywatnych wraz 


\section{Plany gospodarcze wobec planów zagospodarowania przestrzennego}

Środkiem normatywnym zapewniającym nadrzędność interesu społecznego nad interesem jednostkowym było także powiązanie planów zagospodarowania przestrzennego z planami społeczno-gospodarczymi. Plany społeczno-gospodarcze były szczególnego rodzaju aktami normatywnymi stanowiącymi podstawę działań administracji państwowej odnoszących się do funkcjonowania gospodarki planowej $^{15}$. Plany społeczno-gospodarcze regulowały procesy gospodarcze, przez co służyły ochronie interesu społecznego. Ich powiązanie z planami zagospodarowania przestrzennego oznaczało, że interes społeczny związany ze sferą gospodarczą państwa powinien był znaleźć swojej odzwierciedlenie w tych planach.

Powiązanie tych planów zostało wprowadzone do polskiego porządku prawnego dekretem z dnia 2 kwietnia 1946 roku o planowym zagospodarowaniu przestrzennym kraju ${ }^{16}$, a później potwierdzone przez przepisy ustawy z dnia 31 stycznia 1961 roku o planowaniu przestrzennym ${ }^{17}$. Prawodawca $\mathrm{w}$ ustawie $\mathrm{z}$ dnia

z wejściem w życie ustawy z dnia 7 lipca 1994 roku o zagospodarowaniu przestrzennym, a dla zamierzeń publicznych - dopiero wraz z wejściem w życie ustawy z dnia 27 marca 2003 roku o planowaniu i zagospodarowaniu przestrzennym (Dz.U. z 2003 r. Nr 80, poz. 717). Zob. M. Szewczyk, Wolność budowlana..., s. 27.

15 W. Brzeziński, Rozwój planów zagospodarowania przestrzennego jako formy prawnej zarzadzania gospodarka narodowa, [w:] Aktualne problemy administracji i prawa administracyjnego, red. A. Jaroszyński, Warszawa 1987, s. 230.

16 Zgodnie $\mathrm{z}$ art. 2 dekretu $\mathrm{z}$ dnia 2 kwietnia 1946 roku o planowym zagospodarowaniu przestrzennym kraju planowe zagospodarowanie przestrzenne, które było przeprowadzane na podstawie planu krajowego, planów regionalnych oraz planów miejscowych, powinno było być zgodne z wytycznymi polityki gospodarczej państwa. Zob. M. Szewczyk, Wolność budowlana..., s. 25. Jak podkreśla W. Brzeziński, miejscowy plan zagospodarowania przestrzennego powinien był być procedowany z uwzględnieniem wytycznych wynikających między innymi z postanowień planów gospodarczych; idem, Administracja budowlana, [w:] Polskie prawo administracyjne. Część szczegółowa, z. 2, red. W. Brzeziński, J. Starościak, Warszawa 1957, s. 26-27. W literaturze podkreśla się, że w pierwszym okresie Polskiej Rzeczypospolitej Ludowej normy planistyczne wyrażone w planach społeczno-gospodarczych były nadrzędne względem norm prawnych z uwagi na potrzebę zapewnienia bodźców ekonomicznych związanych z zapewnieniem postępu i rozwoju gospodarczego oraz społecznego. Idem, Rozwój planów zagospodarowania przestrzennego..., s. 231-232.

17 W świetle art. 1 ust. 2 ustawy z dnia 31 stycznia 1961 roku o planowaniu przestrzennym planowanie przestrzenne powinno było uwzględniać bieżące i przyszłe potrzeby wynikające z programu rozwoju gospodarczego i społecznego. Zgodnie z art. 1 ust. $3 \mathrm{w}$ zw. z art. 1 ust. 1-2 tej ustawy ustalenia planowania przestrzennego powinny były być oparte między innymi na planach perspektywicznych rozwoju gospodarki narodowej oraz na wieloletnich narodowych planach gospodarczych. Zob. M. Szewczyk, Wolność budowlana..., s. 25. M. Szewczyk zauważa także, że ustawa z dnia 31 stycznia 1961 roku o planowaniu przestrzennym stanowiła bardziej ścisłe powiązanie planowania przestrzennego z planowaniem gospodarczym w porównaniu z poprzednimi regulacjami prawnymi. M. Szewczyk, Rozwój regulacji prawnych w Polsce, [w:] Zasady prawa budowlanego i zagospodarowania przestrzennego, red. Z. Leoński, M. Szewczyk, Bydgoszcz-Poznań 2002, s. 28. W.A. Gorzym-Wilkowski uważa, że przepisy ustawy z dnia 31 stycznia 1961 
12 lipca 1984 roku o planowaniu przestrzennym pozostawił powiązanie pomiędzy planami zagospodarowania przestrzennego a planami społeczno-gospodarczymi. Należy jednak zauważyć, że powiązanie pomiędzy tymi dwoma rodzajami aktów planistycznych uległo modyfikacji. Plany zagospodarowania przestrzennego przestały być podległe planom społeczno-gospodarczym, lecz oba rodzaje tych aktów planistycznych stały się względem siebie równoważne ${ }^{18}$. W świetle przepisów ustawy z dnia 12 lipca 1984 roku o planowaniu przestrzennym ustanowiono współzależność planów zagospodarowania przestrzennego z planami społeczno-gospodarczymi ${ }^{19}$. Prawodawca zakładał współzależność tych planów, co oznaczało, że postanowienia planów zagospodarowania przestrzennego wpływały na regulacje planów społeczno-gospodarczych ${ }^{20}$, a postanowienia planów społeczno-gospodarczych wpływały na regulacje planów zagospodarowania przestrzennego ${ }^{21}$.

roku o planowaniu przestrzennym ustanawiały zasadę, że planowanie przestrzenne na poziomie krajowym stanowiło dopełnienie planowania gospodarczego; idem, Pół wieku ewolucji teorii i praktyki planowania przestrzennego w Polsce (1961-2010), [w:] Człowiek w przestrzeni zurbanizowanej, red. M. Soja, A. Zborowski, Kraków 2011, s. 195. Jak podkreśla I. Wich ustawa z dnia 31 stycznia 1961 roku o planowaniu przestrzennym zakładała ścisłe powiązanie planów społeczno-gospodarczych z planami zagospodarowania przestrzennego. Ścisłym powiązaniem tych planów objęte były przenikanie się ich celów i zadań, jak i dostosowanie okresów planowania przestrzennego do okresów właściwych dla planowania perspektywicznego oraz planowania wieloletniego; idem, Rozwój planowania przestrzennego w Polsce, „Annales Universitatis Mariae Curie-Skłodowska. Sectio H, Oeconomia” 1976, nr 10, s. 66. Nauka prawa współczesna dla obowiązywania przepisów ustawy z dnia 31 stycznia 1961 roku o planowaniu przestrzennym zauważała niewystarczające powiązanie pomiędzy planami zagospodarowania przestrzennego a planami społeczno-gospodarczymi. Zdaniem W. Pańki powiązanie planowania przestrzennego oraz planowania gospodarczego było najsłabsze na poziomie planowania miejscowego, a słabe na poziomie planowania regionalnego; idem, Własność gruntowa w planowej gospodarce przestrzennej. Studium prawne, Katowice 1978, s. 91.

18 Jak podkreśla W. Brzeziński, w latach osiemdziesiątych XX wieku zauważono równowagę pomiędzy normami planistycznymi, wyrażonymi w planach społeczno-gospodarczych, a normami prawnymi; idem, Rozwój planów zagospodarowania przestrzennego..., s. 232. Planami zagospodarowania przestrzennego były objęte normy prawne.

19 W świetle art. 4 ust. 1 ustawy z dnia 12 lipca 1984 roku o planowaniu przestrzennym planowanie przestrzenne i planowanie społeczno-gospodarcze są współzależne. Zob. Z. Leoński, Planowanie przestrzenne a prawo budowalne, [w:] Aktualne problemy administracji i prawa administracyjnego..., s. 233. Na współzależność planowania przestrzennego oraz planowania gospodarczego wskazuje także treść art. 17 ust. 1 zd. 1 ustawy z dnia 12 lipca 1984 roku o planowaniu przestrzennym. W świetle tego przepisu projekt planu zagospodarowania przestrzennego kraju był rozpatrywany łącznie z projektem planu perspektywicznego rozwoju społeczno-gospodarczego.

${ }^{20}$ Zgodnie $\mathrm{z}$ art. 4 ust. 2 ustawy z dnia 12 lipca 1984 roku o planowaniu przestrzennym możliwości i ograniczenia rozwoju społeczno-gospodarczego wynikające z planów zagospodarowania przestrzennego powinny stanowić podstawę do określania w planach społeczno-gospodarczych sposobów, proporcji i środków zaspokajania potrzeb społecznych.

21 W myśl art. 4 ust. 3 ustawy z dnia 12 lipca 1984 roku o planowaniu przestrzennym wynikające z planów społeczno-gospodarczych uwarunkowania rozwoju powinny stanowić podstawę do określania w planach zagospodarowania przestrzennego sposobów, proporcji i miejsca realizacji przedsięwzięć służących zaspokojeniu potrzeb społecznych. 
Zgodnie $\mathrm{z}$ art. 2 ust. 1 ustawy z dnia 26 lutego 1982 roku o planowaniu społeczno-gospodarczym ${ }^{22}$ plan społeczno-gospodarczy był aktem planistycznym podjętym przez organ administracji państwowej i nakierowanym na podniesienie

materialnego i kulturalnego poziomu i jakości życia ludności, proporcjonalnego rozwoju gospodarki, podwyższania społecznej efektywności gospodarowania oraz rozwijania i umacniania ekonomicznych podstaw ustroju socjalistycznego.

W świetle art. 1 tej ustawy celem systemu planów społeczno-gospodarczych było kształtowanie aktywnego rozwoju gospodarczego z wykorzystaniem mechanizmu rynkowego zgodnie z założeniami socjalistycznego systemu gospodarczego.

W myśl tych regulacji plany społeczno-gospodarcze służyły ochronie interesu społecznego związanego z działaniami gospodarczymi organów administracji państwowej. Powiązanie planów społeczno-gospodarczych z planami zagospodarowania przestrzennego skutkowało uwzględnieniem w tym planowaniu ochrony interesu społecznego związanego z aktywnością gospodarczą państwa. Należy podkreślić, że w planach zagospodarowania przestrzennego nie uwzględniono ochrony interesu jednostkowego związanego z planowaną aktywnością gospodarczą jednostki. Skutkiem powiązania tych dwóch rodzajów planów jest zatem nadrzędność interesu społecznego względem interesu jednostkowego.

Przepisy ustanawiające powiązanie planów społeczno-gospodarczych i planów zagospodarowania przestrzennego obowiązywały do dnia 17 grudnia 1990 roku, gdy została uchylona ustawa z dnia 26 lutego 1982 roku o planowaniu społeczno-gospodarczym ${ }^{23}$.

\section{Zakończenie}

Polski prawodawca w przepisach ustawy z dnia 12 lipca 1984 roku o planowaniu przestrzennym ustanowił między innymi środki normatywne zapewniające nadrzędność interesu społecznego nad interesem jednostkowym w planowaniu przestrzennym. Środkami tymi były zasada zabudowy planowej oraz powiązanie planów zagospodarowania przestrzennego z planami społeczno-gospodarczymi. Środki te służyły podporządkowaniu interesu jednostki dobru społecznemu rozumianemu z perspektywy ideologii socjalizmu. Miały one charakter autorytarny, ponieważ były związane z nadmiernym ograniczeniem swobód jednostki i możliwości ochrony jej interesów. Skutkiem przemian ustrojowych było wyeliminowanie tych środków normatywnych z polskiego porządku prawnego. Zmiany

${ }^{22}$ Ustawa z dnia 26 lutego 1982 roku o planowaniu społeczno-gospodarczym (Dz.U. z 1982 r. $\mathrm{Nr} 7$, poz. 51).

$23 \mathrm{~W}$ świetle art. 1 ustawy z dnia 30 listopada 1990 roku o uchyleniu ustawy o planowaniu społeczno-gospodarczym oraz o zmianie niektórych ustaw (Dz.U. z 1990 r. Nr. 87, poz. 505) została uchylona ustawa z dnia 26 lutego 1982 roku o planowaniu społeczno-gospodarczym. 
te następowały jednak stopniowo i były związane z szerszymi zmianami prawa dotyczącymi odpowiednio: uchwalenia ustawy z dnia 7 lipca 1994 roku o zagospodarowaniu przestrzennym oraz uchylenia ustawy z dnia 26 lutego 1982 roku o planowaniu społeczno-gospodarczym.

\section{Bibliografia}

\section{Akty normatywne}

Dekret z dnia 2 kwietnia 1946 roku o planowym zagospodarowaniu przestrzennym kraju (Dz.U. z 1946 r. Nr 16, poz. 109).

Ustawa z dnia 31 stycznia 1961 roku o planowaniu przestrzennym (Dz.U. z 1961 r. Nr. 7, poz. 47). Ustawa z dnia 26 lutego 1982 roku o planowaniu społeczno-gospodarczym (Dz.U. z 1982 r. Nr 7, poz. 51).

Ustawa z dnia 12 lipca 1984 roku o planowaniu przestrzennym (Dz.U. z 1984 r. Nr 35, poz. 185).

Ustawa z dnia 30 listopada 1990 roku o uchyleniu ustawy o planowaniu społeczno-gospodarczym oraz o zmianie niektórych ustaw (Dz.U. z 1990 r. Nr 87, poz. 505).

Ustawa z dnia 7 lipca 1994 roku o zagospodarowaniu przestrzennym (Dz.U. z 1994 r. Nr 89, poz. 415). Ustawa z dnia 27 marca 2003 roku o planowaniu i zagospodarowaniu przestrzennym (Dz.U. z 2003 r. $\mathrm{Nr} 80$, poz. 717).

\section{Literatura}

Błażewski M., Zasada wolności budowlanej. Studium administracyjnoprawne, Wrocław 2016.

Brzeziński W., Administracja budowlana, [w:] Polskie prawo administracyjne. Część szczegółowa, z. 2, red. W. Brzeziński, J. Starościak, Warszawa 1957.

Brzeziński W., Rozwój planów zagospodarowania przestrzennego jako formy prawnej zarządzania gospodarka narodowa, [w:] Aktualne problemy administracji i prawa administracyjnego, red. A. Jaroszyński, Warszawa 1987.

Bużowicz M., Ewolucja prawa własności w Polsce Ludowej w latach 1944-1956, „Wrocławskie Studia Erazmiańskie. Studia Erasmiana Wratislaviensia" 2016, nr 10.

Gorzym-Wilkowski W.A., Pót wieku ewolucji teorii i praktyki planowania przestrzennego w Polsce (1961-2010), [w:] Człowiek w przestrzeni zurbanizowanej, red. M. Soja, A. Zborowski, Kraków 2011.

Górski J., Kilka uwag w sprawie własności, „Nowe Drogi” 1951, nr 6.

Kania R., Między ideologia i praxis. Organizacja socjalistyczna w PRL w latach 1956-1981, „Studia nad Autorytaryzmem i Totalitaryzmem" 41, 2019, nr 4.

Leoński Z., Planowanie przestrzenne a prawo budowalne, [w:] Aktualne problemy administracji i prawa administracyjnego, red. A. Jaroszyński, Warszawa 1987.

Pańko W., Własność gruntowa w planowej gospodarce przestrzennej. Studium prawne, Katowice 1978.

Paruch W., Autorytaryzm w Europie XX wieku. Zarys analizy politologicznej cech systemu politycznego, „Annales Universitatis Mariae Curie-Skłodowska. Sectio K. Politologia” 16, 2009, nr 1.

Szewczyk M., Rozwój regulacji prawnych w Polsce, [w:] Prawo zagospodarowania przestrzennego, red. Z. Leoński, M. Szewczyk, M. Kruś, Warszawa 2019. 
Szewczyk M., Rozwój regulacji prawnych w Polsce, [w:] Zasady prawa budowlanego i zagospodarowania przestrzennego, red. Z. Leoński, M. Szewczyk, Bydgoszcz-Poznań 2002.

Szewczyk M., Wolność budowlana i zasada zabudowy planowej, „Przegląd Budowlany” 2013, nr 6. Tokarczyk R., Autorytaryzm - dociekanie istoty pojęcia, „Historia i Polityka” 2009-2010, nr 2-3. Wich I., Rozwój planowania przestrzennego w Polsce, „Annales Universitatis Mariae Curie-Skłodowska. Sectio H, Oeconomia” 1976, nr 10.

\section{Orzecznictwo}

Wyrok NSA z dnia 7 sierpnia 2013 roku, II OSK 165/12, CBOSA. 